\author{
Gatot Sasongko' \\ Niken Putri Artanti ${ }^{2}$ \\ Andrian Huruta ${ }^{3}$ \\ Cheng-Wen Lee ${ }^{4}$
}

JEL: C23, E2, J08

DOI: 10.5937/industrija48-29455

UDC: $330.34(594)$

331.56(594)

Original Scientific Paper

\title{
Reexamination of Okun's law: Empirical analysis from Panel Granger Causality
}

\author{
Article history: \\ Received: 18 November 2020 \\ Sent for revision: 10 December 2020 \\ Received in revised form: 18 December 2020 \\ Accepted: 22 December 2020 \\ Available online: 31 December 2020
}

Abstract: This study aims to confirm the existence of Okun's coefficients in Indonesia. Authors conducted panel data of 34 provinces in Indonesia for the period from 2014 to 2019, obtained from the Central Bureau of Statistics. The data were analyzed by using the panel data model and Panel Granger Causality. The Panel Granger causality analysis results show that there was one-way causality between the economic growth and the unemployment. It was caused by several influencing factors, such as education level, population, and employment opportunities. Based on the Fixed Effect Model and Panel Granger Causality results, authors conclude that Okun's Law has not been proven for 34 provinces in Indonesia.

Keywords: Okun's Coefficient, Open Unemployment, Economic Growth, Panel Data, Panel Granger Causality

\section{Preispitivanje Okunovog zakona: Empirijska analiza primenom Grejndžerovog testa uzročnosti}

Apstrakt: Cilj ovog rada je da potvrdi postojanje Okunovih koeficijenata u Indoneziji. Autori su sproveli panel analizu podataka o 34 provincije u Indoneziji u periodu od 2014. do 2019. godine, dobijenih od strane Državnog zavoda za statistiku. Podaci su analizirani korišćenjem panel modela analize podataka $i$ Grejndžerovog testa uzročnosti. Rezultati Grejndžerovog testa uzročnosti

\footnotetext{
1 Satya Wacana Christian University

${ }^{2}$ Satya Wacana Christian University

${ }^{3}$ Chung Yuan Christian University, g10804610@cycu.edu.tw

${ }^{4}$ Chung Yuan Christian University
} 
pokazuju da je postojala jednosmerna uzročnost između ekonomskog rasta $i$ nezaposlenosti. Uzrok tome je nekoliko uticajnih faktora, kao što su nivo obrazovanja, populacija i mogućnosti zaposlenja. Na osnovu modela fiksnog efekta i rezultata Grejndžerovog testa uzročnosti, autori zaključuju da Okunov zakon nije dokazan za 34 provincije u Indoneziji.

Ključne reči: Okunov koeficijent, otvorena nezaposlenost, ekonomski rast, panel podaci, Grejndžerov test uzročnosti.

\section{Introduction}

Changes in economic structure, national institutions, and community life behavior are multidimensional development processes. In economic development, one of the goals to be achieved is to create the broadest employment opportunity. A full employment opportunity means that the unemployment rate and inflation will decrease, along with high-quality economic growth that creates financial stability in line with macroeconomic goals (United Nations, 2008).

Mankiw (2016) postulates that macroeconomists analyze many aspects of the economy. They discuss the role of savings in economic growth, the impact of minimum-wage legislation on the unemployment, the effect of inflation on interest rates, and the impact of trade policy on trade and exchange-rate balances. Material standards of living have increased significantly over time for most families in most countries. This advance comes from rising revenues, which have made it possible for individuals to consume more essential quantities of goods and services. Economists use gross domestic product data to measure economic growth. The gross domestic product measures the total income of everyone in a countries' economy. The Solow growth model is designed to show how growth in the capital stock, growth in the labor force, and advances in technology interact in an economy and affect a nation's total output of goods and services.

Skill-biased technological progress has been outpaced by developments in educational achievement during the twentieth century. In other words, while technological advancement has increased the demand for skilled workers, the supply of skilled workers has grown much faster in our education system. As a consequence, economic growth has not benefited from qualified employees significantly (Mankiw, 2016). Indonesia is a developing country that still has problems with high unemployment and unskilled workers. Every year, the available employment opportunities have not been able to accommodate the increasing surge in labor. It is the result of the growing population (Central Bureau of Statistics, 2020a). Limited employment opportunities has become a 
barrier for workers to get a job, resulting in the unemployment (Buzzeo, Marvell, Everett, \& Newton, 2016).

Figure 1. Indonesia Gross Regional Domestic Product (GRDP) and Open Unemployment Rate per province (2019)

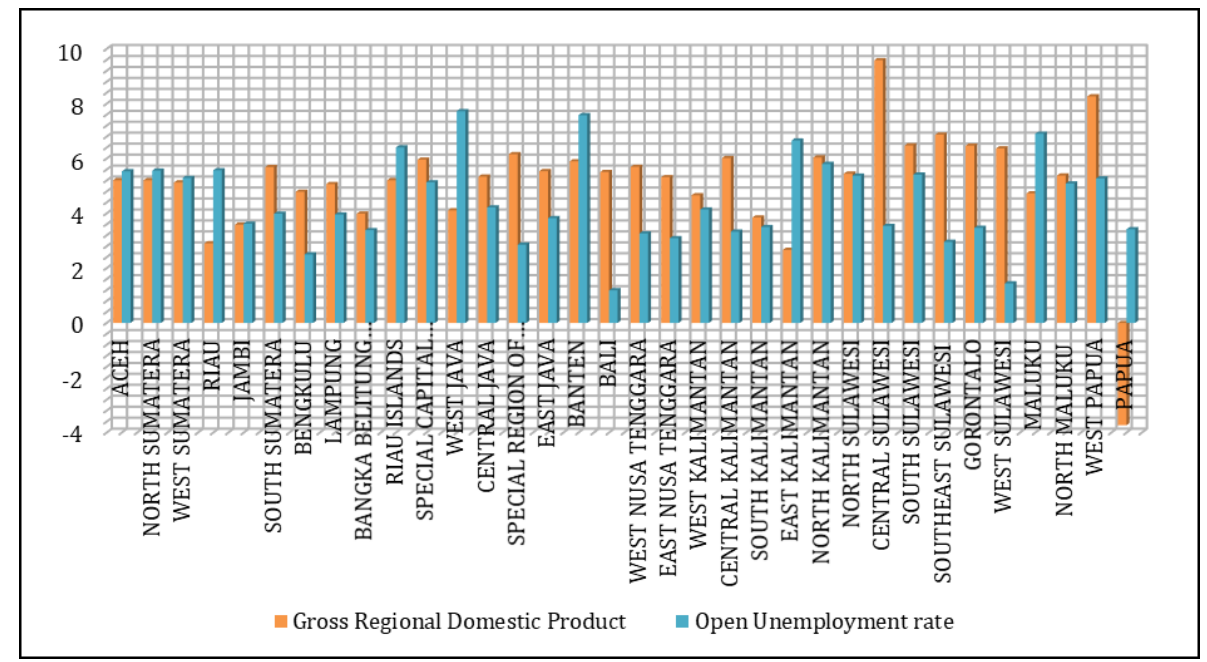

Source: Central Bureau of Statistics (2019)

Figure 1 shows that in 2019, the West Java Province had the highest open unemployment of $7.73 \%$ in the short term. However, it was $8.17 \%$ in 2018 . The high open unemployment is inversely proportional to West Java's economic growth rate, which was lower than the unemployment rate of $4.11 \%$ or decreased by $0.13 \%$ compared to 2018 . While the highest economic growth was in Central Sulawesi Province, at 9.59\%, the increased economic growth results in the unemployment fell by $3.54 \%$. Meanwhile, the economic Growth in Central Sulawesi experienced a significant increase compared to 2018 with a growth rate of $4.74 \%$. There was an increase of $4.85 \%$ in 2019 .

Furthermore, under certain conditions, economic growth could experience a recession, which can be interpreted as a slump of real GDP to a negative value. The same situation also occurd in Papua Province, with a negative economic growth of $-3.73 \%$ or a drastic decrease of $9.21 \%$ compared to 2018 . The economic recession in Papua Province resulted in a reduction of economic sectors' activities, resulting in reduced production capacity. The termination of employment and unemployment was the real impact. In Papua Province, the economic recession resulted in an increase in the unemployment by $0.22 \%$ compared to 2018. 
Another problem that still represents the main focus in Indonesia as a developing country is the unemployment rate. Also, another study by Darman (2013) shows different findings. The economic growth had a positive and not significant effect on the unemployment rate. It means that if economic growth increased, the unemployment rate would also increase. Several factors are causing the positive direction of the relationship. One of them relates to the economic structure changes that generally represent a cause of the situation that an increased economic growth fails to reduce the number of the unemployed. It shows that there is a change in real output that does not respond to the unemployment rate. The experts believe that mainly because there is structural unemployment due to changes in the economic structure. In developing countries like Indonesia, intensive labors are still dominating compared to the skilled ones.

This study analyzes the causal relationship between those two variables in Indonesia based on the inconsistent findings reflecting the relationship between the economic growth and the unemployment rate. Researches specifically discussing causality have also been carried out by Noor et al. (2007) in Malaysia. They found out that there was a two-way causality relationship between economic growth variables and the unemployment rate. Similar findings were also found in several European countries, Africa, and Indonesia (Awad, Hallam, \& Alialhuseen, 2018; Valadkhani \& Smyth, 2015).

Meanwhile, the previous studies found a one-way causality between the economic growth and the unemployment rate (Demirbaş \& Kaya, 2015; Palombi, Perman, \& Tavéra, 2015) and a one-way causality between the unemployment rate and economic growth (Batavia, 2012; Caporale \& Škare, 2011; Gedek, Misiak, \& Mentel, 2017). Indonesia's geographical condition, which consists of many islands, has caused macro policies that cannot be applied equally in all regions. The main reason is that there are aspects of regional differences in each province, which require a lengthy implementation process. As such, this study uses panel data and Granger causality analysis to see the variations in all 34 provinces in Indonesia. This method is an alternative to capture the causal possibilities between economic growth and Indonesia's open unemployment rate.

Indonesia is a developing archipelagic country consisting of 34 provinces. This geographical condition leads to different economic policy implementation in each province, making each result unique and different. The economic growth rate and the unemployment rate are essential in economic development, especially in developing countries like Indonesia. Both have varying degrees of growth and the number of the unemployed in each province over the past six years. Several different findings of other researchers on the causality or causal relationship between these two variables are interesting. As such, this study's 
research problem is whether there's a causal relationship between the economic growth rate and the open unemployment rate from 2014 to 2019.

\section{Literature review}

Okun's Law explains that if there is an increase in the unemployment rate, there will be a decrease in the real output (Mankiw, 2016). To see the relationship between the two variables, Okun's Law has formulated the following equation.

$$
U-U^{n}=-0.5 x\left(Y-Y^{p}\right)
$$

Note:

$\mathrm{U} \quad=$ Unemployment rate

$U^{n} \quad=$ Unemployment in year $n$

$\mathrm{Y} \quad=$ Economic growth

$\mathrm{Yp}_{\mathrm{p}} \quad=$ Potential economic growth

Okun's Law also states that when the economic growth is more than $2.5 \%$ or when there is an increase in real Gross Domestic Product of $1 \%$, the unemployment rate will decrease by $0.5 \%$ (Mankiw, 2016). Prior studies had been carried out by using various methods and different research periods. In Indonesia, Huruta, Sasongko, and Saputri (2020) show a one-way causal relationship from real GDP to the open unemployment rate, but not vice versa. Similarly, the Vector Error Correction Model test shows the significant negative relationship between real GDP and the open unemployment rate. The results imply that changes in GDP affect the unemployment rate.

Similarly, Cetin, Gunaydın, Cavlak, and Topcu (2015) prove a one-way relationship, where economic growth could influence the unemployment rate. The coefficient of OLS shows a negative and significant relationship. It indicates that an increase in the economic growth rate could reduce the unemployment rate. Abdul-Khaliq, Soufan, and Shihab (2014) demonstrate that economic growth negatively affects the unemployment rate. Al-hosban and Edienat (2017) reveale that a 100 million Dinar increase in real GDP will reduce the unemployment rate by 40 percent. Alamro and Al-dala'ien (2016) find that a one percent increase in the economic growth reduces the unemployment rate by 0.007 percent in Jordan. Further, Soylu, Çakmak, and Okur (2018) show that economic growth negatively impacts the unemployment rate.

Meanwhile, Lee and Huruta (2019) find that the open unemployment rate does Granger cause gross domestic product, but not vice versa. In line with the 
Structural Vector Auto-regression, there is a negative relationship between GDP and the open unemployment rate. Bande and Martın-RoMan (2017) demonstrate that the unemployment rate has a significantly negative impact on GDP growth. Kargi (2016) proves the inverse relationship between unemployment and growth, as indicated by the high unemployment rate, will reduce GDP. Ruxandra (2015) finds that the unemployment rate is negatively related to outputs, as suggested by Okun's coefficient of -0.61 . Zanin and Marra (2012) show the highest of Okun's coefficients with significantly negative signs. Also, Awad et al. (2018) find a negative and significant relationship between unemployment and economic growth. It indicates that the unemployment rate influenced economic growth.

Furthermore, the Granger analysis reveals that the unemployment rate influenced Israel's economic growth and vice versa. Therefore, it could be concluded that there is a two-way causality relationship. In Malaysia, Noor et al. (2007) indicate that Okun's coefficient value of -1.75 is significant at the level of $1 \%$. The Granger causality test results prove the two-way relationship between the economic growth and the unemployment. Further, Demirbaş and Kaya (2015) reveal a negative and significant coefficient between the two variables. The causal relationship also shows the two-way relationship between the two variables in the long run.

There is not always a significant relationship between the unemployment rate and output. Akram, Hussain, Raza, and Masood (2014) show that Okun's law is not valid in the Pakistani economy. Arewa and Nwakanma (2012) find that Okun's coefficient is insignificant in the Nigerian economy. It means that a one percent increase in the unemployment rate reduces outputs by 3 percent is invalid. Caraiani (2009) proves the Okun's coefficients are between -0.15 and 0.20 with insignificant distribution at average posterior results. Zanin (2014) indicates that the estimated Okun's coefficient is not always statistically significant for each population subgroup.

In short, these phenomena do not only happen in Indonesia but also in various countries. Researches on the relationship's direction and causality relationship between the economic growth rate and open unemployment are mixed. Previous studies confirmed the two-way and one-way causality relationship with different coefficient levels and research methods and various indications of influencing factors such as education, workforce, and employment opportunity level. Therefore, researches on the causality relationship and proof of the Okun's Law have been empirical studies in various countries. Based on these findings, the following hypotheses were suggested:

$\mathrm{H}_{0}$ : There is no causal relationship between economic growth and the open unemployment rate. 
$\mathrm{H}_{1}$ : There is a causal relationship between economic growth and the open unemployment rate.

\section{Methodology}

Indonesia is the largest archipelago country in the world consisting of 17,504 islands. It has thousands of islands stretching from Sabang to Merauke. Administratively, Indonesia consists of 34 provinces. This study is based on the using of secondary data (economic growth and open unemployment) that comes from the Indonesia Central Bureau of Statistics. According to the World Bank (2020), economic growth refers to the annual percentage growth rate of GDP at market prices based on constant local currency. Besides, International Labor Organization postulate that open unemployment is measured by workers who are willing to work, but have given up on active seeking of new jobs (Islam \& Chowdhury, 2008).

Authors use a Panel Granger causality analysis with panel data consisting of cross-section and time-series data of the economic growth rate and the open unemployment rate from 2014 to 2019. The initial step was to test the stationarity of panel data (Granger, 1969). The unit root test technique used in this study was the Levin, Lin, and Chu (LLC) technique with the following models (Winarno, 2015).

$$
Y_{i t}=\rho_{i} Y_{i t-1}+X_{i t} \delta_{i}+\epsilon_{i t}
$$

In the traditional panel data, three models could be used, including Common Effect Model, Fixed Effect Model, and Random Effect Model.

$$
\begin{aligned}
& Y_{i t}=\alpha_{0}+\beta X_{i t}+e_{i t} \\
& Y_{i t}=\alpha_{0 i}+\beta_{1} X_{i t}+\beta_{2} d_{1 i} \ldots+ \\
& \beta_{33} d_{32 i}+e_{i t} \\
& Y_{i t}=\alpha_{0 i}+\beta X_{i t}+e_{t}
\end{aligned}
$$

The heteroscedasticity could be detected if there was a significant effect on the remaining absolute value's independent variable.

$$
|\mu|_{i}=\alpha+\beta X_{i}+v_{i}
$$

The panel Granger Causality test has been done to detect the causality relationship's direction between economic growth and open unemployment (Granger, 1969). 


\section{Findings}

The stationarity test was performed to see whether there was an average condition of constant variation of data.

Table 1. Stationarity Test

\begin{tabular}{|c|c|c|c|}
\hline Variable & Degree of Integration & Probability & Conclusions \\
\hline GRDP & Level & 0.0000 & Stasionary \\
\hline Open Unemployment & Level & 0.0000 & Stasionary \\
\hline
\end{tabular}

Source: Authors' study

The GRDP shows a probability value less than the significance level $(0.05)$ based on the results. Similarly, open unemployment offers a probability value less than the significance level (0.05). As such, it could be concluded that the two variables were stationary in the degree of integration level $(I(0))$.

After understanding that the data were stationary, the Chow and Hausman test was performed to understand the best estimation model between the Random Effect Model and Fixed Effect Model.

Table 2. Chow and Hausman Test

\begin{tabular}{|c|c|c|}
\hline Test & Probability & Best Model \\
\hline Chow & 0.0000 & Fixed Effect Model \\
\hline Hausman & 0.0324 & Fixed Effect Model \\
\hline
\end{tabular}

Source: Authors' study

Based on the Chow test results, the probability value is 0.0000 , which is less than 0.05. Thus, the best model to use was the Fixed Effect Model, compared to the Common Effect Model. Next, the Hausman test result show a probability value of 0.0324 , which is less than 0.05 . Thus, the Fixed Effect Model is better than the Random Effect Model. It indicates that the Fixed Effect Model was an appropriate estimation model to explain the short-term relationship between the economic growth rate and the open unemployment rate in all provinces in Indonesia.

In the classical assumption test in linear regression, several stages should be taken, one of which was the heteroscedasticity test. 
Table 3. Chow and Hausman Test

\begin{tabular}{|c|c|}
\hline \multicolumn{2}{|c|}{ Dependent Variable : RESABS } \\
\hline Variable & Probability \\
\hline Open Unemployment & 0.3232 \\
\hline
\end{tabular}

Source: Authors' study

Table 3 proves that the residual value has homoscedasticity. It can be seen that the probability value of the dependent variable of RESABS with open unemployment is proven to be higher than the significance value $(0.05)$. It indicates that residuals did not have heteroscedasticity.

The assumption in the Fixed Effect Model explains that slopes between individuals are the same, but intercepts within individuals are different.

Table 4. Fixed Effect Model Test

\begin{tabular}{|l|c|c|c|}
\hline \multicolumn{1}{|c|}{ Variable } & Coefficient & t-statistic & Probability \\
\hline C & 4.931147 & 52.92445 & 0.0000 \\
\hline GRDP & 0.039810 & 2.338248 & 0.0205 \\
\hline R-Square & 0.927914 & & \\
\hline Prob. (F-Statistic) & 0.000000 & & \\
\hline
\end{tabular}

Source: Own study

Table 4 indicates that the coefficient is positive and significant at 0.03 , showing a positive relationship between the economic growth and the unemployment. Therefore, if economic growth increased, unemployment would also increase. This particular finding contrasts with the theory of Okun's Law, which explains that the increase in economic growth would lower unemployment statistically. It means that Okun's Law has not been proven for 34 provinces in Indonesia. Next, the probability value obtained is bigger than 0.05 , proving that the economic growth rate positively and significantly relates to Indonesia's open unemployment rate.

Furthermore, after conducting the Fixed Effect Model test, it was essential to pay attention to the constant differences between this study subjects.

Table 5 notes that out of 34 provinces in Indonesia, $60 \%$ of them have a constant negative value, which implied that, in case Indonesia's economic growth reached zero, the unemployment rate would decrease with a constant value. Among the provinces, those with negative constant value are: Jambi, South Sumatera, Bengkulu, Lampung, Bangka Belitung, Central Java, Yogyakarta, East Java, Bali, West Nusa Tenggara, East Nusa Tenggara, West Kalimantan, Central Kalimantan, South Kalimantan, Central Sulawesi, North Sulawesi, Gorontalo, West Sulawesi, North Maluku, and Papua. Among these, 
$40 \%$ are provinces with a positive constant value, which indicated that, when the economic growth reached zero, the open unemployment rate would increase along with a constant value.

Table 5. Cross Section Effect

\begin{tabular}{|c|c|c|c|}
\hline Province & Effect & Province & Effect \\
\hline Aceh & 2.457038 & West Nusa Tenggara & -0.868036 \\
\hline North Sumatera & 0.785364 & East Nusa Tenggara & -1.839644 \\
\hline West Sumatera & 0.679990 & West Kalimantan & -0.757374 \\
\hline Riau & 1.632175 & Central Kalimantan & -1.140022 \\
\hline Jambi & -0.983830 & South Kalimantan & -0.611996 \\
\hline South Sumatera & -0.472463 & East Kalimantan & 2.192076 \\
\hline Bengkulu & -1.552104 & North Kalimantan & 0.524877 \\
\hline Lampung & -0.645876 & North Sulawesi & 1.861014 \\
\hline Bangka Belitung & -0.947092 & Central Sulawesi & -1.634872 \\
\hline Riau Islands & 1.769303 & South Sulawesi & 0.157258 \\
\hline Jakarta & 1.558399 & Southeast Sulawesi & -1.477857 \\
\hline West Java & 3.236993 & Gorontalo & -1.288850 \\
\hline Central Java & -0.372002 & West Sulawesi & -2.430278 \\
\hline Yogyakarta & -1.915908 & Maluku & 3.345799 \\
\hline East Java & -1.034432 & North Maluku & -0.081397 \\
\hline Banten & 3.678519 & West Papua & 1.307133 \\
\hline Bali & -0.868036 & Papua & -1.603322 \\
\hline
\end{tabular}

Source: Authors' study

A lag length test was performed to see how much the optimal lag would be used in the research model. The optimal lag was needed for the next step to understand the causality relationship between the variables.

Table 6. Lag Length Test

\begin{tabular}{|c|c|c|c|c|c|c|}
\hline Lag & LogL & LR & FPE & AIC & SC & HQ \\
\hline 0 & -415.4063 & NA & 12.28875 & 8.184437 & 8.235907 & 8.205279 \\
\hline 1 & -302.0852 & 219.9763 & 1.440752 & 6.040886 & 6.195296 & 6.103412 \\
\hline 2 & -281.4737 & 39.20216 & 1.040368 & 5.715171 & 5.972521 & 5.819381 \\
\hline 3 & -269.8439 & $21.66346^{*}$ & $0.896053^{*}$ & $5.565566^{*}$ & $5.925856^{*}$ & $5.711460^{*}$ \\
\hline
\end{tabular}

Source: Authors' study

Table 6 proves that lag three was used to determine the economic growth rate and open unemployment. The AIC value of 5.565566 is smaller than the AIC value in other lags. It proved that the lag 3 was suitable to be used as a determinant of causality in the panel Granger causality test. The lagged reaction of the labor market to the changes in GDP growth is important. According to Lee and Huruta (2020), the average working hours per week show an increasing trend. The facts indicate that this number had increased from 37 72 
hours in 1986 to 41 hours in 2017. When the GDP increases, it should be followed by an increase in labor demand. The increase in the average working hours illustrates the fulfillment of labor needs did not originate from the additional number of workers but from the additional number of working hours. Furthermore, we use the panel Granger causality test to determine the relationship between the variables. In this test, optimal lag was needed to estimate the model.

Table 7. Panel Granger Causality Test

\begin{tabular}{|c|c|c|}
\hline Null Hypothesis & F-stat & Probability \\
\hline GRDP $\rightarrow$ Open Unemployment & 3.63105 & 0.0157 \\
\hline Open Unemployment $\rightarrow$ GRDP & 2.13803 & 0.1005 \\
\hline
\end{tabular}

Source: Authors' study

Table 7 shows the hypothesis - stating that there is no Granger causality relationship between economic growth and open unemployment is not supported empirically. It is proven by the probability value of 0.0157 , which is smaller than the significance value $(0.05)$. Meanwhile, the other hypothesis stating that there is no causal relationship between open unemployment and economic growth - can be supported empirically by the probability value of 0.1005 , which is bigger than the significance value $(0.05)$. It could be concluded that there was a unidirectional causality from economic growth to open unemployment.

Okun's Law explains that if there is an increase in the unemployment rate, there will be a decrease in the real output (Mankiw, 2016).

\section{Discussion}

The Fixed Effect Model reveals that economic growth positively impacts the open unemployment. Therefore, the findings are similar to those of Huruta, Sasongko, and Saputri (2020), Cetin, Gunaydın, Cavlak, and Topcu (2015), Abdul-Khaliq, Soufan, and Shihab (2014), Al-hosban and Edienat (2017), Alamro and Al-dala'ien (2016), Soylu, Çakmak, and Okur (2018) which prove that economic growth has the negative impact on the unemployment rate. However, these findings are not in line with Okun's Law assumption, which explains that open unemployment has a negative and significant effect on economic growth. The Okun's coefficient in the Fixed Effect Model test results is only $0.03 \%$. It means that, when the economic growth rate increased by $1 \%$, it would reduce the open unemployment by $0.03 \%$ in Indonesia from 2014 to 2019, both in the long and short term. Furthermore, conducted Granger causality test indicates a one-way relationship between economic growth and 
open unemployment. A similar thing also happened in a previous study that found a one-way causality relationship in the economic growth, affecting the open unemployment, although it had different coefficient results (Demirbaş \& Kaya, 2015; Palombi et al., 2015).

It was common in developing countries such as Indonesia to be capital intensive (Lee \& Huruta, 2019). Employers in developing countries were high profit-oriented by using existing technologies and reducing the number of employees they needed. Entrepreneurs tried to maximize profits, efficiency, and product. The need for labor in capital-intensive industries was mostly dominated by high educational qualifications that were still highly needed to support productivity and balance scientific-technological progress. Thus, it could be concluded that workers with low academic qualifications had low employment opportunities. An increase in economic growth would lead to a rise in the unemployment rate. In this case, open unemployment was such an endogenous factor that could change depending on the changes. Based on the latest education completed, the proportion of unemployed can be seen in Figure 2.

Figure 2. Open Unemployment According to Highest Education Completed in 2014 to 2019

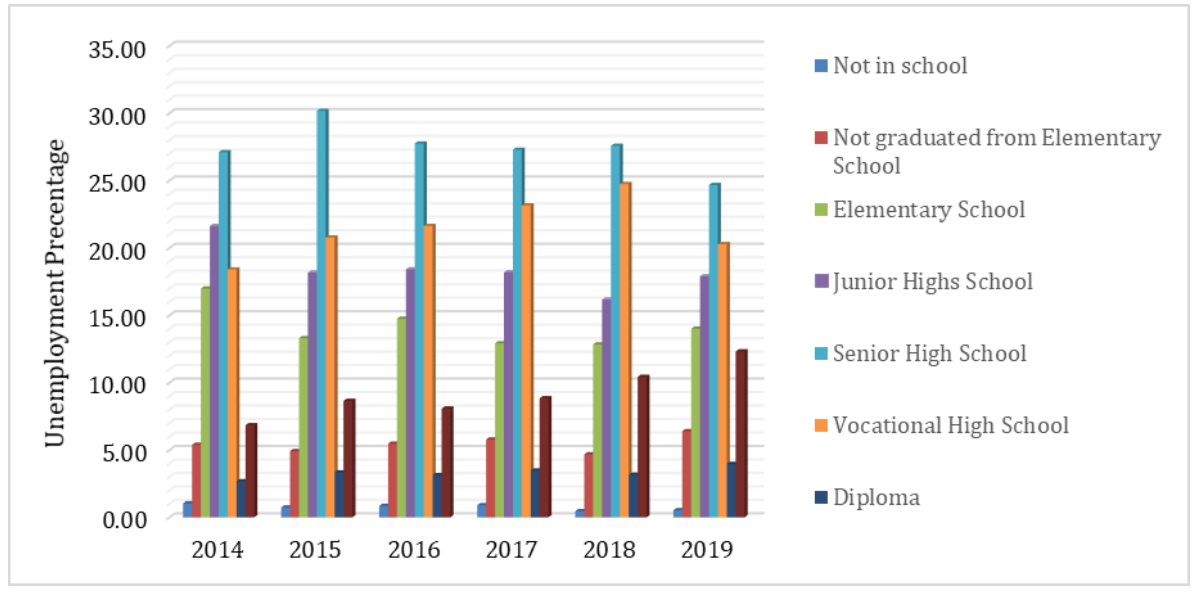

Source: Central Bureau of Statistics (2020)

Figure 2 indicates that unemployment based on the latest education completed in the past six years fluctuates. It also shows that high school graduates dominate the quantity of open unemployment. In 2015, the number of unemployed high school graduates was the highest, reaching $30.16 \%$ or $2,280,029$ individuals from the total workforce. The unemployed percentage at 
the senior high school level increased by $3.07 \%$ from 2014 , and decreased by $2.42 \%$ to $27.74 \%$ of the total workforce in 2016 . The decline continued in 2017 , although it only decreased by $0.46 \%$, increased by $0.29 \%$ in 2018 , and decreased by $2.91 \%$ in 2019 .

The finding that the labor market does not only require high-level educational qualifications, but more specific expertise in a field was also worth considering. It was different compared to the unemployed at the Vocational High School level. Training in more specific areas could encourage graduates to be accepted in the labor market. At the same time, there not many unemployed diploma graduates compared to undergraduate graduates. It happened because employers prefer to hire workers with diploma degrees in the professional world as they were considered less theoreticaly oriented and more ready to work. Therefore, the available employment opportunities had not been absorbed by the entire workforce. The employment opportunity shows that everyone has the opportunity to get a job in their area of expertise. It is shown in Table 8.

Table 8. Number of Unemployed, Workers, Number of Labor Force and Employment Opportunity in Indonesia from 2014 to 2019

\begin{tabular}{|c|c|c|c|c|}
\hline \multicolumn{1}{|l|}{ Year } & \multicolumn{1}{l|}{ Workers } & Unemployed & \multicolumn{1}{l|}{ Labor Force } & Opportunity \\
\hline 2014 & $114,628,026$ & $7,244,905$ & $121,872,931$ & 94.06 \\
\hline 2015 & $114,819,199$ & $7,560,822$ & $122,380,021$ & 93.82 \\
\hline 2016 & $118,411,973$ & $7,031,775$ & $125,443,748$ & 94.39 \\
\hline 2017 & $121,022,423$ & $7,040,323$ & $128,062,746$ & 94.50 \\
\hline 2018 & $124,004,950$ & $7,000,691$ & $131,005,641$ & 94.66 \\
\hline 2019 & $129,366,192$ & $6,816,840$ & $136,183,032$ & 94.99 \\
\hline
\end{tabular}

Source: Central Bureau of Statistics (2020b)

Table 8 shows that the average percentage of employment opportunities ammounted $93-94 \%$ from 2014 to 2019. According to Statistics Indonesia, the tendency to increase employment opportunities since 2015 represent a form of success of the Government's Work Plan targets in 2018 and the National Medium-Term Development Plan in 2015 to 2019. The peak recorded that the number of people working in 2018-2019 increased by 5.3 million individuals with an increase in employment opportunities by $0.57 \%$. This achievement was also a reflection of the success of economic development in Indonesia. The expansion of productive employment opportunities could increase production output to improve economic growth simultaneously. In terms of the effect of economic growth on the employment in Indonesia, a panel data test of 34 provinces in Indonesia is presented in Table 9. 
Table 9. Effect of Economic Growth on Employment Opportunity by Province

\begin{tabular}{|c|c|c|c|c|}
\hline Variable & Coefficient & Std. Error & t-Statistic & Probability \\
\hline GRDP & 0.174346 & 0.057051 & 3.055946 & 0.0026 \\
\hline
\end{tabular}

Source: Authors' study

Table 9 reveals a positive direction of the coefficient of 0.174346 . It indicates a positive relationship between economic growth and employment opportunities in all provinces in Indonesia from 2014 to 2015. This positive relationship implied that, if the economic growth's trend increased, the level of employment opportunities would also increase. According to the classical economic theory by Adam Smith, in order to reduce the unemployment rate, any increase in economic growth was expected to be able to cause the absorption of labor. In this case, human resources development was closely related to the rise in the economic growth rate, as seen in the theory of efficiency and productivity. Through human resource development, a skilled and productive workforce could be obtained. Education and training aim to develop the potential of human resources. In other words, education is one of the factors driving economic growth. The higher the open unemployment rate, the more it will reduce purchasing power. Therefore, it could bring an impact on decreasing economic growth. The lack of available employment opportunities drove the decline in purchasing power.

According to Abramovitz and Solow's neo-classical theory, the development of production factors could affect economic growth. The intended production factors could be in the form of capital, labor, population, and technological advance. Without the production factors with a pretty good specification, the result would only be a decrease in productivity that had implications fon the economic growth rate (Noor et al., 2007). This study's positive coefficient was different from the coefficient based on Okun's Law, which is negative, indicating the influence of several other factors explaining its existence.

\section{Conclusions}

Based on this study's results, Okun's Law has not been proven in 34 provinces in Indonesia in the period from 2014 to 2019. The test results showed a positive and significant coefficient of $0.03 \%$. It demonstrates that if there is a $1 \%$ increase in the economic growth, it would undoubtedly add to the open unemployment by $0.03 \%$. Furthermore, the Granger causality test shows a oneway causality relationship where the economic growth affected open unemployment, as evidenced by a smaller probability value than 0.05 . The results confirmed that when the economic growth increases, unemployment 
would also increase, and it could be explicitly explained by the factors that influence it.

However, increased economic growth might not necessarily reduce unemployment. It should be noted that the needs of the labor market based on the latest completed educational qualifications are still dominating. Therefore, it could reduce employment opportunities for the workers who did not have enough academic qualifications and for the workers with less suitable educational qualifications for the available employment. In the 6-year-period (2014 to 2019), the highest unemployment was found in senior high school graduates compared to the vocational high school graduates. The latter was superior because they gained more specific expertise in certain fields, which made them more acceptable in the labour market. The unemployment of diploma graduates is less than of bachelor graduates because they are considered to be more ready to work in business than theoretically oriented.

Based on Statistics Indonesia data, employment opportunities had increased from 2014 to 2015, although not too significant. According to the results of simple regression done in this study, it happened as the impact of increased economic growth. Nevertheless, the unemployment rate still remained. It is possible that several factors outside the model were influenced, such as the rate of population growth and the influence of capital-intensive industries in Indonesia.

Based on this study's results and conclusion, Indonesia's increasing economic growth will increase unemployment in the long run. It is highly related to the unidirectional relationship that occurs when the economic growth simultaneously affects the unemployment rate. As a policy authority, the government is advised to make policies related to job creation that are more productive and absorb more labor. The government needs to pay attention to all sectors that contribute to the real GDP as a benchmark for reducing the unemployment rate so that the growth rate will bring the expected impacts. However, the implementation will be different in each province in Indonesia due to the archipelago geographical condition. As such, the government should also make more policies related to pre-employment training that will support individual's skills to become qualified human capital in the labor market, especially in case of the unemployed high school graduates.

\section{References}

Abdul-Khaliq, S., Soufan, T., \& Shihab, R. A. (2014). The Relationship between Unemployment and Economic Growth Rate in Arab Country. Journal of Economics and Sustainable Development, 5(9), 56-60. Retrieved from 
https://www.iiste.org/Journals/index.php/JEDS/article/view/13213

Akram, M., Hussain, S., Raza, S. H., \& Masood, S. (2014). An Empirical Estimation of Okun's Law in Context of Pakistan. Journal of Finance and Economics, 2(5), 173177. https://doi.org/10.12691/jfe-2-5-7

Al-hosban, S., \& Edienat, M. (2017). The Validity of Okun's Law, Case of Jordan. European Scientific Journal, 13(28), 470-486. https://doi.org/10.19044/esj. 2017.v13n28p470

Alamro, H., \& Al-dala'ien, Q. (2016). Validity of Okun's Law: Empirical Evidence from Jordan. Dirasat, Administrative Sciences, 43(1), 315-324. Retrieved from http://journals.ju.edu.jo/DirasatAdm/article/view/6788

Arewa, A., \& Nwakanma, P. C. (2012). Potential-Real GDP Relationship and Growth Process of Nigerian Economy: an Empiriical Re- Evaluation of Okun's Law. European Scientific Journal, 8(9), 25-33. Retrieved from https://eujournal.org/index.php/esj/article/view/143

Awad, I., Hallam, A., \& Alialhuseen, M. (2018). Testing the Validity of Okun's Rule of Thumb Across Palestine and Israel. Review of Applied Economics, 13(1-2), 3754.

Bande, R., \& Martın-RoMan, A. L. (2017). Regional differences in the Okun's Relationship: New Evidence for Spain (1980-2015). In Munich Personal RePEc Archive Paper (No. 79833). Retrieved from https://mpra.ub.unimuenchen.de/79833/

Batavia, A. R. (2012). Relationship between Unemployment and Gross Domestic Product: Evidence from Pakistan using Okun's Law. Journal of Independent Studies and Research-Management, Social Sciences and Economics, 10(1), 149-157. https://doi.org/10.31384/jisrmsse/2012.10.1.10

Buzzeo, J., Marvell, R., Everett, C., \& Newton, B. (2016). Tackling unemployment among disadvantaged young people. United Kingdom.

Caporale, G. M., \& Škare, M. (2011). Short- and Long-Run Linkages Between Employment Growth, Inflation and Output Growth : Evidence From a Large Panel. In Economic and Finance Working Paper. Retrieved from https://www.brunel.ac.uk/_data/assets/pdf_file/0011/127487/1117.pdf

Caraiani, P. (2009). Bayesian Linear Estimation of Okun Coefficient for Romania: Sensitivity to Priors. The Romanian Economic Journal, 38(25), 53-65. Retrieved from http://www.rejournal.eu/sites/rejournal.versatech.ro/files/articole/2010-1201/2112/caraiani-je38.pdf

Central Bureau of Statistics. (2019). Laju Pertumbuhan Produk Domestik Regional Bruto Atas Dasar Harga Konstan 2010 Menurut Provinsi, 2010-2018 (Persen). Retrieved from Central Bureau of Statistics website: https://www.bps.go.id/dynamictable/2015/10/07/961/-seri-2010-lajupertumbuhan-produk-domestik-regional-bruto-atas-dasar-harga-konstan-2010menurut-provinsi-2010-2018-persen-.html

Central Bureau of Statistics. (2020a). Laborer Situation in Indonesia. Retrieved from Central Bureau of Statistics website: https://www.bps.go.id/publication/ 2020/06/19/43f6d15bcc31f4170a89e571/keadaan-pekerja-di-indonesia-februari2020.html

Central Bureau of Statistics. (2020b). Penduduk Berumur 15 Tahun Ke Atas Menurut Pendidikan Tertinggi yang Ditamatkan dan Jenis Kegiatan Selama Seminggu yang Lalu, 2008-2019. Retrieved from Central Bureau of Staistics website: 
https://www.bps.go.id/statictable/2016/04/05/1909/penduduk-berumur-15-tahunke-atas-menurut-pendidikan-tertinggi-yang-ditamatkan-dan-jenis-kegiatanselama-seminggu-yang-lalu-2008-2019.html

Central Bureau of Statistics. (2020c). Tenaga Kerja. Retrieved from Central Bureau of Staistics website: https://www.bps.go.id/subject/6/tenaga-kerja.html\#subjek View Tab5

Cetin, M., Gunaydın, D., Cavlak, H., \& Topcu, B. (2015). Unemployment and its Impact on Economic Growth in the European Union: An Evidence from Panel Data Analysis. In Regional Economic Integration and the Global Financial System (pp. 12-22). Turkey: IGI Global Press.

Darman. (2013). Effect of Economic Growth on Unemployment Rate: Analysis of Okun's Law. The Winners, 14(1), 1-12.

Demirbaş, E., \& Kaya, M. V. (2015). Impact of GDP Growth on Unemployment During the Expansion Periods: a Study on Okun's Law for Turkey. Dumlupınar Üniversitesi Sosyal Bilimler Dergisi, (46), 84-95.

Gedek, S., Misiak, T., \& Mentel, G. (2017). Changes in GDP and the employment and unemployment in the European Union. Transformations in Business and Economics, 16(3C), 42-59.

Granger, C. W. J. (1969). Investigating Causal Relations by Econometric Models and Cross-spectral Methods. Econometrica, 37(3), 424-438. https://doi.org/10.2307/1912791

Huruta, A. D., Sasongko, G., \& Saputri, R. C. (2020). An Empirical Test of Okun's Coefficient in Indonesia. Review of Integrative Business and Economics Research, 9(s4), 140-156.

Islam, I., \& Chowdhury, A. (2008). Menyatakan Strategi Ketenagakerjaan Nasional untuk Indonesia: Apa yang Kita Ketahui dan Apa yang Sebaiknya kita Lakukan? Jakarta: International Labor Organization.

Kargi, B. (2016). Okun's Law and Long Term Co-Integration Analysis for OECD Countries (1987-2012). Emerging Markets Journal, 6(1), 39-46. https://doi.org/10.5195/emaj.2016.92

Lee, C.-W., \& Huruta, A. D. (2019). Okun's law in an emerging country: An empirical analysis in Indonesia. International Entrepreneurship Review, 5(4), 141-161. https://doi.org/10.15678/IER.2019.0504.09

Mankiw, N. G. (2016). Macroeconomics (9th ed.). New York: Worth Publisher.

Noor, Z. M., Nor, N. M., \& Ghani, J. A. (2007). The relationship between output and unemployment in Malaysia: Does Okun's Law exist? International Journal of Economics and Management, 1(3), 337-344.

Palombi, S., Perman, R., \& Tavéra, C. (2015). Regional growth and unemployment in the medium run: asymmetric cointegrated Okun's Law for UK regions. Applied Economics, 47(57), 6228-6238. https://doi.org/10.1080/00036846.2015.1068922

Ruxandra, P. (2015). The Specifics Of Okun's Law In The Romanian Economy Between 2007 And 2013. Annals - Economy Series, 1(II), 50-53. Retrieved from http://www.utgjiu.ro/revista/ec/pdf/2015-01.Volumul 2/07_Pitorac.pdf

Soylu, Ö. B., Çakmak, I., \& Okur, F. (2018). Economic growth and unemployment issue: Panel data analysis in Eastern European Countries. Journal of International Studies, 11(1), 93-107. https://doi.org/10.14254/2071-8330.2018/11-1/7

United Nations. (2008). Achieving Sustainable Development and Promoting 
Development Cooperation. New York: United Nations Publications.

Valadkhani, A., \& Smyth, R. (2015). Switching and asymmetric behaviour of the Okun coefficient in the US: Evidence for the 1948-2015 period. Economic Modelling, 50, 281-290. https://doi.org/10.1016/j.econmod.2015.07.001

Winarno, W. W. (2015). Analisis Ekonometrika dan Statistika dengan Eviews (4th ed.). Yogyakarta: UPP STIM YKPN.

World Bank. (2020). Metadata Glossary. Retrieved from World Bank website: https://databank.worldbank.org/metadataglossary/jobs/series/NY.GDP.MKTP.KD .ZG

Zanin, L. (2014). On Okun's law in OECD countries: An analysis by age cohorts. Economics Letters, 125(2), 243-248. https://doi.org/10.1016/j.econlet. 2014.08.030

Zanin, L., \& Marra, G. (2012). Rolling regression versus time-varying coefficient modelling: An empirical investigation of the Okun's law in some Euro area countries. Bulletin of Economic Research, 64(1), 91-108. https://doi.org/10.1111/j.1467-8586.2010.00376.x 